\title{
Public relations winners celebrate collections, caftelogs, services, and more
}

\author{
By Evelyn Riché Olivier
}

\section{College and special libraries win Jobn Cotton Dana Special Awards}

5 he University of California, Santa Barbara, Library, the Diablo Valley College Library, and the MacNeal Hospital Health Science Resource Center were three winners of note to college and special librarians in this year's John Cotton Dana (JCD) Library Public Relations Awards contest.

A total of 16 awards for library public relations, including two John Cotton Dana Awards and 14 Special Awards, were presented at the 1992 American Library Association Annual Conference in San Francisco. This prestigious competition, now in its 53 rd year, is open to all types of libraries and is cosponsored by the $\mathrm{H}$. W. Wilson Company and the ALA Library Administration and ManJoin us in celebrating
the inauguration of new Library Automation System

ALICE
4Acces; to Library Information
for College Education"
Thursday, August 30,1990
1:30 p.m. Plibon Cutting Ceremony
DVC Library
2:00 p.m. Alice's Tea Party
Library lawn

\section{ALICE}

Acces; to Library Information or College Education"

Thursday, August 30, 1990 DVC Library

Don't be late for a wery important date!!

An invitation to celebrate the inauguration of Diablo Valley College's new library automation system showing "Alice" at the computer. the inauguration of
Diablo Valley College's

lic relations program introducing a new online library catalog. An Alice in Wonderland theme was chosen to introduce "ALICE" (Access to $\mathrm{Li}^{-}$ brary Information for College Education), the new system that was so named in a contest sponsored by the DVC Library. This publicly supported community college has approximately 24,000 students, a full-time faculty of 300 , a part-time faculty of 450 , and is located in Pleasant Hill, California, 35 miles east of San Francisco. DVC is one of three colleges in the Contra Costa Community College District and offers the Associate of Arts degree as well

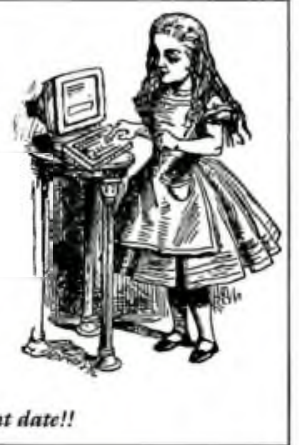

as technical-vocational and terminal programs.

The goals of the DVC's winning library public relations campaign were to develop awareness and name recognition for ALICE, to welcome the system in a joyful and lighthearted atmosphere, and to create a desire among the students, faculty, and staff to come to the library and use agement Association. Of the 106 total entries for the 1992 JCD contest, 21 came from college/university or special library categories.

\section{Alice in Wonderland}

A Special Award winner, the Diablo Valley College (DVC) Library was recognized for its pubthe system. Other measurable objectives were also proposed and included plans to increase the use of the library, to increase the number of bibliographic instruction lectures, and to increase the circulation of library materials.

A very successful inaugural event was held during the second week of the 1990 fall semes- 
ter featuring costumed students, balloons, banners, buttons, speakers, a ribbon cutting, a Tea Party, and croquet. Instruction on the use of ALICE was the prominent focus and the varied offerings included workshops for faculty, bibliographic instruction orientations, drop-in instruction, brochures, instructional guides, orientations for college support staff, and demonstrations to area librarians and educators.

The entire library staff was proud to be involved in a campaign that generated much enthusiasm on the part of the college community for the new online catalog and other library services. Their contest entry noted that this was the first major public relations activity undertaken by the DVC Library in the 40 years of its history. They describe this experience as one in which "the library staff has recognized the continuing benefits of public relations in achieving the goal of effectively serving the students, faculty, and staff of the college."

\section{Two million reasons to celebrate}

The University of California, Santa Barbara (UCSB), Library won one of the 14 Special Awards given for exceptional public relations efforts that support a special project, goal, or activity from the library's total public relations program. UCSB launched a week-long series of events during National Library Week, April 1519, 1991, to celebrate the acquisition of the library's two-millionth volume. The major goals of the program were to cuitivate public involvement in the celebration, to develop a high profile for the library, and to enhance the library's fundraising efforts.

The UCSB Library serves a campus of approximately 19,000 students and 1,000 faculty. UCSB is a major research institution and part of the state-supported, nine-campus University of California system. The Santa Barbara area has a population of about 175,000 and the UCSB Library is the only research library for this area.

The public relations program "Two Million Reasons to Celebrate" met its goals by targeting special groups from the university and Santa Barbara communities, increasing press coverage of the UCSB Library, and raising funds for the purchase of the 15th-century French Book of Hours which became the library's two-millionth volume. Events hosted during National Library Week included a two-day symposium on Freedom of Information with participation from librarians, journalists, lawyers, and uni- versity faculty; a lecture by Susan Sontag on "Writer's Freedom: Literature and Literacy," a talk for area librarians by Linda Crismond, then executive director of ALA, and the dedication of UCSB's new online catalog, PEGASUS. The celebration concluded with the public presentation of the two-millionth volume and a reception.

A most attractive and original aspect of this project was the use of the Book of Hours as the two-millionth volume and the symbol for the celebration. The Book of Hours offered a tangible and interesting focus for the celebration as well as providing exciting visual images. A miniature from the book was used whenever possible for illustrating public relations materials. The slogan "Two Million Reasons to Celebrate" used with the miniature illustration provided a strikingly effective graphic identity for the program (see this month's cover).

\section{More winning ideas}

Need new ideas to promote your library? Consider trying a few of these public relations activities from past John Cotton Dana contest participants:

- sponsor a cultural or ethnic festival that features library materials, staff, and services;

- revamp and revitalize your library orientation program with a new jazzy video introduction;

- host an information literacy program;

- feature special library collections with an authors conference or seminar;

- raise funds for the library with a celebrity roast or other special event;

- celebrate National Library Week every year and be creative;

- promote without fail a new library building, remodeling project, dedication, or anniversary;

- introduce with great fanfare library automation projects, new services, and collections;

- prepare eye-catching exhibits displaying library materials or hot topics of interest;

- give your library publications a positive new graphic identity;

For best PR results involve your users and Friends, have a sense of humor, do something fun, and always say thank you! 
The success of the celebration was measured by a large and diverse attendance at library programs, extensive publicity enhancing the UCSB Library profile, and fundraising in excess of $\$ 35,000$. Much of the planning of the week's events involved the Friends of the UCSB Libraries, who also contributed funds for production of the public relations materials.

\section{The phone is our front door}

The MacNeal Hospital Health Science Resource Center (HSRC), a special library in Illinois, won an award for the entry "The phone is our front door." The Health Science Resource Center was specifically cited "for innovatively promoting
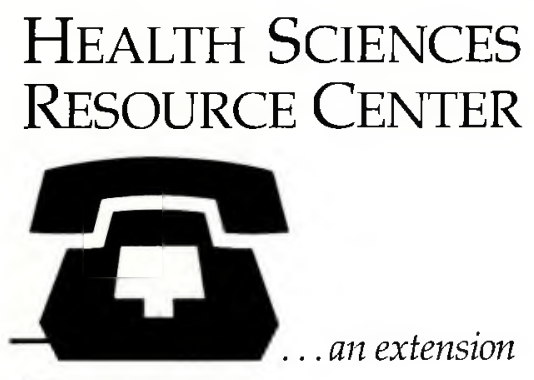

MacNeal Hospital's logo promoting telephone access to the Health Science Resource Center. the library's telephone accessibility to both the medical and general communities."

The HSRC submitted a unique public relations contest entry based on its need to be perceived as convenient to use, despite its relocation across the street from the hospital in April 1991. Of equal importance was the center's desire to be valued for its integral role in the achievement of excellence in health care. Located in Berwyn, Illinois, the MacNeal Hospital and its nine satellites are spread throughout eight buildings on several city blocks. The HSRC, which serves the informa-

\section{Feature your collection on a cover of C\&RL News}

If you have material in your library's collections that you think would make an attractive GERL Neus cover, please send us a photograph and a brief description of the item and the collection. Photos may be either color or black and white and should be $5^{\prime \prime} \times 7^{\prime \prime}$ or $8^{\prime \prime} \times 10^{\prime \prime}$. Illustrations with a vertical orientation work best. Materials submitted will become the property of CERL News and cannot be acknowledged. Send to: CERL News Covers, 50 E. Huron St., Chicago, IL 60611. tion needs of the medical and professional staff and the population served by the hospital, is not conveniently located to any of its users.

A major goal of the center's public relations campaign was to encourage and redirect traffic from walk-in access to primarily telephone, telefacsimile, and modem access. The staff specifically hoped to overcome the obstacles of lack of time, inclement weather, and the psychological barrier of being the only hospital department located across a busy intersection. After the center's move the first event held was an open house which coincided with the introduction of a new

CD Plus Net 1 network. The timing of the event was linked to the arrival of new residents and the monthly meeting of the largest group of physicians. The open house was used to demonstrate new technology, to sign up users for passwords and individualized training, and to show off the new state-of-the-art library facility.

Access to the Health Science Resource Center by telephone was creatively promoted using a logo illustrating a telephone with a line going off the page and the accompanying phrase "an extension of your office, accessible by phone." This identifying symbol was used on all library materials and on 500 coffee mugs which were made up and distributed.

The usage statistics provided bear out the success of the HSRC's public relations program. Services are more popular than ever by phone or fax and the ability of users to do their own computer searches by remote access to the new CD Plus System has enhanced the usage of this and other services of the center.

\section{Make plans to enter now}

Share your public relations successes by entering the 1993 John Cotton Dana Library Public Relations Awards Contest. Entry packets and contest information are available from the Marketing Department, H. W. Wilson Company, 950 University Avenue, Bronx, NY 10452. The contest deadline is February 1, 1993. 


\section{ACQUISITION PERSPECTIVES}

4. We have established a reputation for accuracy in billing and shipping to your specifications. Invoices arranged alphabetically by author or title, or numerically by purchase order, and separate billing available upon request for Grant Funds, Title II, gifts, etc. Book House error rate last year was less than $1 / 3$ percent.

\section{ANY BO0K IN PRINT}

\section{CONPLA' DAHWRT}

\section{OPAN ORDAR RAPORTS}

\section{STRNDHA ORDHAS}

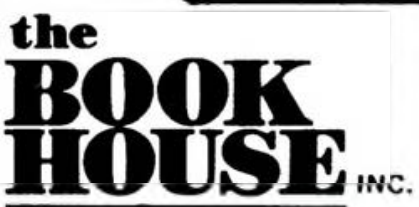

Since 1962

JOBBERS SERVING LIBRARIES WITH ANY BOOK IN PAINT SINCE 1982 208 WEST CHICAGO STREET JONESVILLE, MICHIGAN 492500125

\section{Call or Write TODAY}

$1 \cdot 800 \cdot 248 \cdot 1146$

FAX: $517 \cdot 849 \cdot 9716$ 